\title{
Isolasi, Identifikasi Senyawa Alkaloid Dan Uji Efektivitas Penghambatan Dari Ekstrak Daun Sirih (Piper betle L.) Terhadap Bakteri Staphylococcus epidermidis
}

\author{
Gwendolyn Louradebi Kapondo, ${ }^{1}$ Fatimawali, $^{1}$ Meilani Jayanti ${ }^{1}$
}

\author{
${ }^{1}$ Program Studi Farmasi Fakultas Matematika Ilmu Pengetahuan Alam Universitas Sam \\ Ratulangi Manado \\ Email: gwenkapondo@gmail.com
}

\begin{abstract}
Betel leaf (Piper betle L) contains alkaloid compounds and has antibacterial and antiseptic functions. The purpose of this research was to isolated alkaloid compounds also to tested the effectiveness of inhibition of the betel leaf extract against the Staphylococcus epidermidis bacterial growth. Simplicia betel leaf was extracted used $96 \%$ of ethanol solvent. Antibacterial activity tested of betel leaf extract with a concentration variation of $25 \%, 20 \%$, $15 \%, 10 \%$ and $5 \%$ using the liquid dilution method. The results of identification of alkaloid isolates used UV-Vis Spectrophotometry method can be known alkaloid compounds contained in betel leaves include alkaloids with indole base framework that was absorption at $262 \mathrm{~nm}$ and $274 \mathrm{~nm}$ wavelengths. The results of the effectiveness of betel leaf on Bacteria Staphylococcus epidermidis used the liquid dilution method showed that betel leaf extract with Optical density values at concentrations of 25\%,20\%, 15\% and 10\% before and after incubation decreased respectively by $-0.347,-0.304,-0.192$ and -0.104 , while at a concentration of 5\% there was increase in Optical density values of 0.162 . From the results of the research, it can be concluded that the ethanol extract of betel leaf contains an alkaloid with an indole base framework and was inhibitory activity against Staphylococcus epidermidis bacteria with a MIC at a concentration of $10 \%$.
\end{abstract}

Keywords: betel leaf, Staphylococcus epidermidis, alkaloid compound, aiquid dilution.

\begin{abstract}
Abstrak: Daun Sirih (Piper betle L) mengandung senyawa alkaloid dan memiliki fungsi sebagai antibakteri dan antiseptik. Penelitian ini bertujuan untuk mengisolasi senyawa alkaloid dan menguji efektivitas penghambatan dari ekstrak daun sirih hijau terhadap pertumbuhan bakteri Staphylococcus epidermidis. Simplisia daun sirih hijau diekstraksi dengan menggunakan pelarut etanol 96\%. Uji aktivitas antibakteri ekstrak daun sirih dengan variasi konsentrasi $25 \%, 20 \%, 15 \%, 10 \%$ dan 5\% menggunakan metode dilusi cair. Hasil identifikasi terhadap isolat alkaloid menggunakan metode Spektrofotometri UV-Vis dapat diketahui senyawa alkaloid yang terkandung dalam daun sirih termasuk alkaloid dengan kerangka dasar Indol yang mempunyai serapan pada panjang gelombang $262 \mathrm{~nm}$ dan $274 \mathrm{~nm}$. Hasil uji efektivitas daun sirih terhadap bakteri Staphylococcus epidermidis dengan metode dilusi cair menunjukan bahwa ekstrak daun sirih dengan nilai densitas optik pada konsentrasi 25\%, 20\%, $15 \%$ dan $10 \%$ sebelum dan sesudah inkubasi mengalami penurunan berturut-turut sebesar $0.347,-0.304,-0.192$ dan -0.104 , sedangkan pada konsentrasi $5 \%$ mengalami kenaikan nilai densitas optik sebesar 0.162. Dari hasil penelitian yang diperoleh, dapat disimpulkan bahwa ekstrak etanol daun sirih mengandung alkaloid dengan kerangka dasar indol dan memiliki aktivitas penghambatan terhadap bakteri Staphylococcus epidermidis dengan KHM pada konsentrasi $10 \%$.
\end{abstract}

Kata Kunci: Daun Sirih, Staphylococcus epidermidis, Senyawa Alkaloid, Dilusi Cair. 


\section{PENDAHULUAN}

Penyakit yang disebabkan oleh bakteri memiliki peringkat yang cukup tinggi. Belakangan ini, salah satu masalah kulit wajah yang sering dijumpai anak remaja dan orang dewasa adalah timbulnya jerawat. ${ }^{1}$ Infeksi bakteri dan kosmetik merupakan masalah utama penyebab jerawat. Staphylococcus epidermidis merupakan salah satu bakteri yang menyebabkan penyakit jerawat, bakteri ini merupakan flora normal di kulit. Penyebab lain penyakit jerawat karena adanya zat nutrisi bagi bakteri yang diproduksi dari sekresi kelenjar sebasea yakni air, urea, garam dan asam lemak. $^{2}$

Senyawa-senyawa metabolit sekunder terdapat di dalam tumbuhan. Salah satu senyawa metabolit sekunder adalah alkaloid. Efek fisiologis senyawa tersebut sangat bermanfaat dalam pengobatan. Alkaloid kebanyakan bersifat basa. Sifat tersebut tergantung adanya pasangan elektron pada nitrogen penyusunnya. Umumnya alkaloid di dalam tumbuhan terikat dengan asam organik membentuk garam. Garam ini yang diekstraksi dengan pelarut organik yang sesuai. Pelarut etil asetat dan kloroform memiliki sifat semipolar sehingga dapat baik melarutkan alkaloid. ${ }^{3}$

Berdasarkan uraian tersebut, peneliti tertarik untuk melakukan penelitian (Isolasi, identifikasi senyawa alkaloid dan uji efektivitas penghambatan dari ekstrak daun sirih (Piper betle L.) terhadap bakteri Staphylococcus epidermidis) dengan metode dilusi untuk membuktikan apakah daun sirih dapat menghambat bakteri Staphylococcus epidermidis.

\section{METODE PENELITIAN}

Penelitian ini dilakukan pada bulan November 2019 - Februari 2020 di laboratorium Farmasi Lanjutan Program Studi Farmasi Fakultas Matematika dan Ilmu Pengetahuan Alam Universitas Sam Ratulangi Manado.

Determinasi tanaman dilakukan di Laboratorium Biologi Dasar, Program Studi Biologi, Fakultas Matematika dan
Ilmu Pengetahuan Alam, Universitas Sam Ratulangi Manado.

Tahap awal sampel daun sirih yang diambil dicatat ketinggian DPL yaitu $27 \mathrm{~m}$ , lintang utaranya yaitu $1^{0} 11^{\prime} 30$ " dan bujur timurnya $124^{0} 35^{\prime} 19^{\prime}$ ". Selanjutnya daun sirih segar yang didapat sebanyak $8 \mathrm{~kg}$ dibersihkan dari kotoran, dicuci dengan air mengalir sampai bersih, dipotong-potong, ditiriskan, dikeringkan menggunakan oven selama 3 hari, ditimbang sampel kering dan dihaluskan dengan blender sampai menjadi serbuk. Sampel yang telah menjadi serbuk di masukan dalam wadah tertutup.

Metode yang digunakan untuk mengekstraksi sampel daun sirih yaitu dengan metode maserasi. Sampel ditimbang sebanyak 750 gr, kemudian dimasukkan ke dalam wadah tertutup rapat. Sampel yang telah ditimbang di ekstraksi dengan 3750 $\mathrm{mL}$ pelarut etanol $96 \%$ pada suhu kamar selama 5 hari sambil sesekali diaduk. Filtrat kemudian diuapkan menggunakan oven, sehingga diperoleh ekstrak kental daun sirih. Ekstrak kental yang diperoleh disimpan dalam wadah tertutup dan dimasukkan dalam lemari pendingin.

Pengujian bebas etanol dilakukan dengan cara dimasukan ekstrak etanol kental sebanyak 1gr ke dalam gelas bekker, ditambahkan asam asetat $1 \mathrm{~mL}$ dan asam sulfat $1 \mathrm{~mL}$ kemudian dipanaskan. Ekstrak dikatakan bebas etanol bila tidak ada bau ester yang khas dari etanol.

Ekstrak kental yang telah didapatkan, diambil sebanyak $10 \mathrm{gr}$ ditambahkan larutan $\mathrm{HCl} 2 \mathrm{M}$ hingga $\mathrm{pH}$ larutan menjadi 3 dimasukan kedalam corong pisah. Ekstrak larutan yang telah bersifat asam kemudian diekstraksi menggunakan etil asetat, sehingga ekstraksi akan terbentuk 2 lapisan, yaitu lapisan asam dan lapisan etil asetat. Selanjutnya kedua lapisan dipisahkan, kemudian lapisan asam ditambahkan $\mathrm{NH}_{4} \mathrm{OH}$ hingga $\mathrm{pH}$ larutan 9 kemudian diekstraksi kembali menggunakan etil asetat. Hasil ekstraksi akan terbentuk 2 lapisan yaitu lapisan basa dan lapisan etil asetat, kemudian dipisahkan. Lapisan etil asetat inilah yang mengandung senyawa alkaloid kemudian lapisan ini dipekatkan menggu- 
nakan oven sehingga didapatkan isolat alkaloid kemudian akan diuji dengan kromatografi lapis tipis.

Isolat alkaloid kemudian diuji dengan dilakukan pemisahan menggunakan KLT dengan fase diam berupa silika gel 60GF 254 dan eluen fase gerak eluen etil asetat: etanol:n-heksan dengan perbandingan 2:1: 3. Kemudian untuk memeriksa keberadaan alkaloid menyemprotkan pereaksi dragendorf. Noda atau bercak yang terbentuk ditandai dan diamati pada sinar UV $\lambda 366$ nm. Hasil positif akan menunjukan warna jingga. Kemudian dilakukan pemisahan menggunakan KLT preparatif $20 \times 20 \mathrm{~cm}$ menggunakan pelarut yang sama. Noda pada KLT dikeruk dan dianalisis menggunakan spektrofotometer UV-Vis.

Isolat yang didapat diidentifikasi dengan menggunakan spektrofotometer UVVis pada panjang gelombang standar 200 $800 \mathrm{~nm}$ untuk memperoleh panjang gelombang maksimum untuk senyawa alkaloid. Jika diketahui bahwa isolat tersebut mempunyai panjang gelombang maksimum ( $\lambda \max )$ sebesar $265 \mathrm{~nm}$ - $275 \mathrm{~nm}$, maka positif mengandung alkaloid.

Satu koloni biakan murni bakteri Staphylococcus epidermidis diambil dengan menggunakan ose steril dari kultur murninya, dipakai untuk peremajaan bakteri 4 tabung reaksi setiap tabung diisi $7 \mathrm{~mL}$ larutan nutrien agar dan selanjutnya diinokulasikan dalam medium nutrien agar (NA) miring, kemudian diinkubasikan dalam inkubator pada suhu $37^{\circ} \mathrm{C}$ selama 1x24 jam. Larutan $\mathrm{H}_{2} \mathrm{SO}_{4} \quad 1 \%$ sebanyak 9,95 $\mathrm{mL}$ dicampurkan dengan larutan $\mathrm{BaCl}_{2} \quad .2 \mathrm{H}_{2} \mathrm{O} \quad 1,175 \%$ sebanyak $0,05 \mathrm{~mL}$ dalam erlenmeyer. Kemudian dikocok sampai terbentuk larutan yang keruh. Kekeruhan ini dipakai sebagai standar kekeruhan suspensi bakteri uji.

Bakteri uji pada media agar miring diambil dengan menggunakan kawat ose steril lalu disuspensikan ke dalam tabung yang berisi $15 \mathrm{~mL}$ larutan $\mathrm{NaCl} 0,9 \%$ dalam tabung reaksi kemudian dikocok hingga diperoleh larutan yang keruh. Kekeruhan ini dipakai sebagai standar kekeruhan suspensi bakteri uji.
Ditimbang ekstrak kental daun sirih sebanyak 7,5 g. Untuk memperoleh konsentrasi $25 \%, 20 \%, 15 \%, 10 \%$ dan $5 \%$, pembuatan larutan uji diawali dari pembuatan larutan uji konsentrasi $25 \%$ ditimbang 2,5g sampel, untuk konsentrasi $20 \%$ ditimbang $2 \mathrm{~g}$ sampel, untuk konsentrasi $15 \%$ ditimbang $1,5 \mathrm{~g}$ sampel, untuk konsentrasi $10 \%$ ditimbang $1 \mathrm{~g}$ sampel, dan untuk konsentrasi $5 \%$ ditimbang $0.5 \mathrm{~g}$ sampel. Lalu masing-masing larutan uji dilarutkan dengan DMSO sedikit hingga larut dan selanjutnya dicukupkan sampai volume $10 \mathrm{~mL}$.

Untuk kontrol positif digunakan 1 kapsul tetrasiklin $500 \mathrm{mg}$, dikeluarkan dari kapsul lalu digerus, dilarutkan dalam aquades $25 \mathrm{~mL}$ lalu dimasukkan ke dalam labu ukur $100 \mathrm{~mL}$ dan dicukupkan volumenya dengan aquadest hingga 100 $\mathrm{mL}$ hingga didapat konsentrasi $5 \mathrm{mg} / \mathrm{ml}$. Selanjutnya diambil $1 \mathrm{ml}$ dari larutan stok tetrasiklin $5 \mathrm{mg} / \mathrm{ml}$ dan ditambahkan aquadest hingga dicukupkan $100 \mathrm{ml}$ sampai didapat konsentrasi $50 \mu \mathrm{g} / \mathrm{ml}$.

Metode yang digunakan adalah dilusi cair dan dilakukan pengulangan sebanyak 3x. Pertama me-nyiapkan 21 tabung reaksi yang sudah steril, 3 tabung reaksi berisi media NB $5 \mathrm{~mL}$ sebagai kontrol negatif, 3 tabung reaksi berisi media $\mathrm{NB} 4 \mathrm{~mL}$, larutan antibiotik pembanding (tetrasiklin) $0,5 \mathrm{~mL}$ dan $0,5 \mathrm{~mL}$ suspensi bakteri sebagai kontrol positif. Selanjutnya untuk 15 tabung reaksi sisanya pada setiap tabung diisi dengan $4 \mathrm{~mL}$ media Nutrient Broth, ditambahkan 0,5 mL larutan uji dan 0,5 mL suspensi bakteri pada tabung reaksi tersebut dan di vortex.

Sebelum diinkubasi, setiap tabung dilusi diamati seksama dan diukur absorbansi pada spektrofotometer UV-Vis panjang gelombang $600 \mathrm{~nm}$. Kemudian seluruh tabung diinkubasi pada suhu $37^{\circ} \mathrm{C}$ selama 24 jam. Setelah diinkubasi, setiap tabung dilusi diamati seksama dan diukur absorbansi kembali pada spektrofotometer UV-Vis pada panjang gelombang $600 \mathrm{~nm}$.

Data yang diperoleh dari data diameter hambat dan variasi konsentrasi pengujian aktivitas antibakteri di lakukan pengolahan 
data dengan menggunakan model penyajian dalam bentuk tabel, gambar dan analisis secara deskriptif.

\section{HASIL PENELITIAN}

Berdasarkan hasil identifikasi yang dilakukan di Laboratorium Biologi FMIPA Universitas Sam Ratulangi dapat dipastikan bahwa tumbuhan yang digunakan ialah benar tumbuhan daun sirih (Piper betle L). Proses ekstraksi menggunakan metode ekstraksi cara dingin, yaitu maserasi menggunakan $3750 \mathrm{~mL}$ pelarut etanol $96 \%$, proses maserasi dilakukan selama 5 hari dan diperoleh ekstrak kental sebanyak $58 \mathrm{~g}$. Dari perolehan ekstrak ini, telah dilakukan perhitungan rendemen. Dengan rendemen sampel yang diperoleh yaitu sebesar $9,375 \%$ dan rendemen ekstrak yang diperoleh yaitu sebesar 7,73\%. Isolasi alkaloid diperoleh lapisan etil asetat dipekatkan menggunakan oven menghasilkan isolat alkaloid sebanyak 1.963 gr.

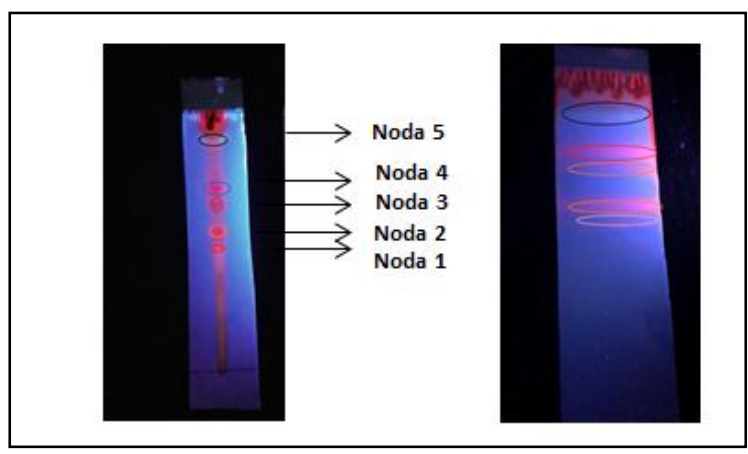

Gambar 1. memperlihatkan hasil KLT dan KLT Preparatif ekstrak alkaloid dengan eluen etil asetat : etanol : n-heksan (2:1:3) panjang gelombang UV $\lambda 366$.

Hasil yang diperoleh pada lampu UV $\lambda 366$ terbentuknya 5 Noda yakni satu buah noda berwarna biru dan empat noda berwarna jingga. Hasil positif akan ditunjukan dengan noda jingga pada plat silica dengan menyemprotkan pereaksi dragendorf. Kemudian dihitung nilai Rf. Nilai $\mathrm{Rf}$ yang diperoleh setelah dihitung adalah 0,78 .

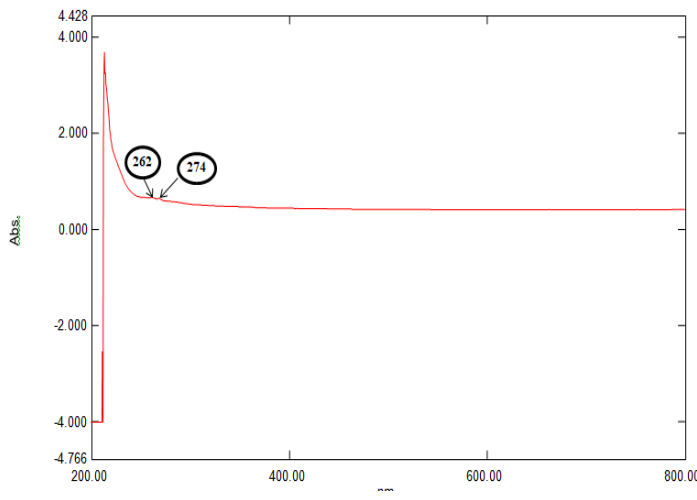

Gambar 2. Hasil Spektrofotometer Ultraviolet (UV-Vis).

Gambar 2 memperlihatkan hasil Spektrofotometer Ultraviolet (UV-Vis). Hasil analisis isolat pada Spektrofotometri UVVis diketahui bahwa isolat tersebut mempunyai panjang gelombang maksimum ( $\lambda \max )$ sebesar $262 \mathrm{~nm}$ dan $274 \mathrm{~nm}$ yang diindikasikan bahwa senyawa tersebut termasuk dalam golongan alkaloid indol.

Tabel 1. Hasil pengukuran daya hambat

\begin{tabular}{|c|c|c|c|c|}
\hline \multirow[b]{2}{*}{$\begin{array}{c}\text { Konsentrasi } \\
(\mathrm{mg} / \mathrm{mL})\end{array}$} & \multicolumn{3}{|c|}{ Nilai rerata OD KHM } & \multirow[b]{2}{*}{ Ket. } \\
\hline & $\begin{array}{l}\text { Sebelum } \\
\text { inkubasi }\end{array}$ & $\begin{array}{l}\text { Sesudah } \\
\text { inkubasi }\end{array}$ & $\Delta \mathrm{OD}$ & \\
\hline $25 \%$ & 0.876 & 0.529 & -0.347 & Turun \\
\hline $20 \%$ & 0.854 & 0.55 & -0.304 & Turun \\
\hline $15 \%$ & 0.841 & 0.649 & -0.192 & Turun \\
\hline $10 \%$ & 0.818 & 0.714 & -0.104 & Turun \\
\hline $5 \%$ & 0.765 & 0.927 & 0.162 & Naik \\
\hline Kontrol (+) & 0.102 & 0.153 & 0.051 & Naik \\
\hline Kontrol (-) & 0.062 & 0.645 & 0.583 & Naik \\
\hline
\end{tabular}

Tabel 1 memperlihatkan hasil pengukuran daya hambat pada uji aktivitas antibakteri menggunakan metode dilusi cair. Dilihat dari tabel 1 konsentrasi 25\% sampai $10 \%$ terjadi penurunan absorbansi sedangkan pada konsentrasi 5\% terjadi kenaikan absorbansi.

\section{BAHASAN}

Berdasarkan hasil identifikasi yang dilakukan di Laboratorium Biologi FMIPA Universitas Sam Ratulangi dapat dipastikan bahwa tumbuhan yang digunakan ialah benar tumbuhan daun sirih (Piper betle L). Proses ekstraksi menggunakan metode ekstraksi cara dingin, yaitu maserasi menggunakan $3750 \mathrm{~mL}$ pelarut etanol $96 \%$, 
proses maserasi dilakukan selama 5 hari dan diperoleh ekstrak kental sebanyak $58 \mathrm{~g}$. Metode maserasi merupakan metode ekstraksi yang paling mudah dan cepat. Filtrat yang dihasilkan kemudian diuapkan menggunakan oven dengan tujuan menguapkan etanol. Proses ekstraksi dilakukan dengan menggunakan pelarut etanol $96 \%$ karena pelarut ini menyari hampir keseluruhan kandungan simplisia baik non polar, semi polar maupun polar. ${ }^{4}$

Pelarut ini bersifat selektif, tidak beracun dan bersifat universal yang cocok untuk mengekstrak semua golongan senyawa metabolit sekunder. ${ }^{5}$ Dari perolehan ekstrak ini, telah dilakukan perhitungan rendemen. Dengan rendemen sampel yang diperoleh yaitu sebesar 9,375\% dan rendemen ekstrak yang diperoleh yaitu sebesar $7,73 \%$.

Isolasi alkaloid, alkaloid kebanyakan bersifat basa. Sifat tersebut tergantung adanya pasangan elektron pada nitrogen penyusunnya. Umumnya alkaloid di dalam tumbuhan terikat dengan asam organik membentuk garam. Garam ini yang diekstraksi dengan pelarut organik yang sesuai. Pelarut etil asetat memiliki sifat semipolar sehingga dapat baik melarutkan alkaloid. Larutan $\mathrm{HCl} 2 \mathrm{M}$ hingga $\mathrm{pH}$ larutan 3 yang bersifat asam agar terbentuk garam alkaloid. Alkaloid akan bereaksi dengan asam kuat akan membentuk garam alkaloid. Larutan yang telah bersifat asam kemudian diekstraksi menggunakan etil asetat.

Lapisan asam berwarna coklat kehijauan dan lapisan etil asetat berwarna merah kecoklatan dilihat pada lampiran 16. Kedua pelarut memiliki berat jenis dan kepolaran yang berbeda. Kedua lapisan tersebut dipisahkan, kemudian lapisan asam ditambahkan $\mathrm{NH}_{4} \mathrm{OH}$ hingga $\mathrm{pH}$ larutan mencapai 9 yaitu larutan basa dilihat pada lampiran 16.

Perlakuan tersebut dilakukan agar garam alkaloid membentuk basa bebas alkaloid. Larutan basa yang telah diekstraksi dengan etil asetat akan membentuk 2 lapisan yaitu lapisan basa dan lapisan etil asetat. $^{6}$ Lapisan etil asetat ini yang mengandung alkaloid, selanjutnya kedua lapisan tersebut dipisahkan. Lapisan etil asetat dipekatkan menggunakan oven menghasilkan isolat alkaloid sebanyak 1.963 gr, kemudian akan dianalisis menggunakan kromatografi lapis tipis.

Isolat alkaloid yang didapat selanjutnya dianalisis menggunakan kromatografi lapis tipis untuk mengetahui jumlah komponennya. Isolat alkaloid yang didapat kemudian dilakukan pemisahan dengan menggunakan KLT fase gerak eluen etil asetat:etanol:n-heksan (2:1:3). Hasil KLT menggunakan plat silika gel 60GF254 dan fasa gerak yang digunakan adalah campuran pelarut etil asetat, etanol dan nheksana $(2: 1: 3)$.

Hasil yang diperoleh pada lampu UV $\lambda 366$ terbentuknya 5 Noda yakni satu buah noda berwarna biru dan empat noda berwarna jingga. Pemisahan pada KLT dikatakan baik jika menghasilkan komponen senyawa berupa noda yang banyak. Eluen yang baik dapat memisahkan noda dalam bentuk jumlah banyak dan selanjutnya akan dianalisis menggunakan KLT preparatif. ${ }^{7}$ Setelah diketahui jumlah komponen senyawa yang terkandung dan mengetahui eluen yang tepat, langkah selanjutnya dilakukan pemisahan menggunakan KLT preparatif.

Hasil positif akan ditunjukan dengan noda jingga pada plat silica dengan menyemprotkan pereaksi dragendorf. Kemudian dihitung nilai Rf. Nilai Rf yang diperoleh setelah dihitung adalah 0,78 . Nilai Rf 0,78 tidak masuk dalam kisaran 12 alkaloid yang paling umum yaitu $0,07-0,62 .^{8}$ Hasil dari nilai $\mathrm{Rf}$ yang berbeda ini dipengaruhi oleh eluen yang digunakan karena Harborne tidak menjelaskan eluen apa yang dipakai, eluen mempengaruhi nilai $\mathrm{Rf}$ karena merupakan fase gerak pada KLT dan dipengaruhi oleh tingkat kepolarannya. Apabila fase diam yang digunakan bersifat polar maka polaritas dari fase gerak akan menentukan nilai Rf, Misal fase diam bersifat polar dan fase gerak bersifat semi polar atau non polar akan menyebabkan harga Rf meningkat secara signifikan. ${ }^{9}$

Hasil pengerokan kemudian diamati pada Spektrofotometri UV-Vis dengan 
panjang gelombang standart 200-800 $\mathrm{nm}$ untuk memperoleh panjang gelombang maksimum untuk senyawa alkaloid. Hasil analisis isolat pada Spektrofotometri UVVis diketahui bahwa isolat tersebut mempunyai panjang gelombang maksimum ( $\lambda$ max) sebesar $262 \mathrm{~nm}$ dan $274 \mathrm{~nm}$ yang diindikasikan bahwa senyawa tersebut termasuk dalam golongan alkaloid indol. Terbentuknya dua buah serapan yang berdekatan menunjukkan ciri khas dari senyawa alkaloid indol, dimana senyawa tersebut mempunyai 2 gugus cincin karbon dengan 1 cincin indol.

Jenis pelarut juga akan mempengaruhi lebar pita yang tampak pada spectrum. Jika pada keadaan transisi tersebut berbeda (karena pengaruh pelarut), maka panjang gelombang absorpsi juga akan sedikit berbeda. ${ }^{9}$ Metode dilusi ini mulai banyak digunakan untuk menguji daya antibakteri suatu senyawa terhadap bakteri.

Serapan yang berbeda-beda dari tiap konsentrasi sebelum diinkubasi dikarenakan mengenai kenaikan nilai rata-rata absorbansi yang bergantung pada zat yang terkandung di dalam larutan, maka semakin banyak molekul yang akan menyerap cahaya pada panjang gelombang tertentu, sehingga nilai absorbansi semakin besar. ${ }^{11}$ Kekurangan dari metode dilusi dengan spektrofotometri UV-Vis dalam selektivitas untuk membedakan sampel dengan partikel-partikel lain yang menyerap cahaya dalam panjang gelombang yang sama, untuk itu konsentrasi sampel berpengaruh terhadap serapan densitas optik (optical density) atau tingkat kekeruhannya sehingga semakin tinggi konsentrasi serapannya juga tinggi. ${ }^{12}$

Dilihat dari Tabel 1 Konsentrasi 25\% sampai $10 \%$ terjadi penurunan absorbansi yang menunjukkan bahwa jumlah sel bakteri yang hidup berkurang dan tidak terjadi pertumbuhan bakteri, dari hasil $\triangle \mathrm{OD}$ yang negatif menunjukkan adanya penurunan nilai absorbansi. ${ }^{13}$ Membuktikan bahwa ekstrak daun sirih mempunyai efektivitas penghambatan terhadap bakteri Staphylococcus epidermidis. Namun pada konsentrasi yang lebih kecil yaitu 5\% terjadi kenaikan nilai absorbansi, hal ini dikarenakan kemampuan ekstrak daun sirih pada konsentrasi ini tidak lagi mampu untuk membunuh dan menghambat pertumbuhan bakteri.

Untuk kontrol negatif mengalami kenaikan dikarenakan pada kontrol negatif tidak diberi perlakuan daun sirih maupun antibiotik, yang membuktikan bahwa media tidak menghambat bakteri. Kontrol positif juga mengalami kenaikan, hal ini diakibatkan tetrasiklin merupakan basa yang sukar larut dalam air, tetapi bentuk garam natrium atau garam $\mathrm{HCl}$-nya mudah larut. Dalam keadaan kering, bentuk basa dan garam $\mathrm{HCl}$ tetrasiklin bersifat relatif stabil. Dalam larutan, kebanyakan tetrasiklin sangat labil jadi berkurang potensinya. ${ }^{14}$

Dari data di atas dapat disimpulkan bahwa konsentrasi terkecil yang masih terjadi penurunan absorbansi merupakan nilai KHM (Konsentrasi Hambat Minimal) dari ekstrak daun sirih yaitu konsentrasi $10 \%$ dimana ekstrak daun sirih bersifat menghambat (bakteriostatik).

\section{SIMPULAN}

Berdasarkan hasil penelitian yang dilakukan dapat di simpulkan bahwa ekstrak daun sirih (Piper betle L) memiliki kandungan senyawa alkaloid jenis indol dengan nilai absorbansi 0.632 dan 0.582 pada panjang gelombang $262 \mathrm{~nm}$ dan 274 nm. Ekstrak daun sirih (Piper betle L) dapat menghambat bakteri Staphylococcus epidermidis dengan terjadinya penurunan densitas optik sebelum dan sesudah inkubasi pada konsentrasi 25\%, 20\%, 15\% dan $10 \%$, dan terjadi kenaikan nilai densitas optic sebelum dan sesudah inkubasi pada konsentrasi $5 \%$, sehingga diperoleh nilai KHM pada konsentrasi $10 \%$.

\section{DAFTAR PUSTAKA}

1. Angelina F, Sabdono A, Delianis P. 2012. Potensi Antibakteri Ekstrak Rumput Laut Terhadap Bakteri Penyakit Kulit. Universitas Diponegoro, Semarang.

2. Khan A.J and Kumar N. 2011. Evaluation of Antibacterial 
properties of Extracts of Piper betle Leaf. Journal Of Pharmaceutical and Biomedical Sciences.11(1).

3. Kakhia,T.I.2012. Alkaloids \& Alkaloids Plans. Adana University Industry Joint Research Center, Turkey.

4. Anshori M dan Iswanti S. 2009. Buku Ajar : Metodologi Penelitian Kuantitatif. Airlangga University Press, Surabaya.

5. Kristanti., Novi, A. 2008. Buku Ajar Fitokimia. Universitas Airlangga Press, Surabaya.

6. Titis, Muhammad, B.M., Fachriyah, E., Kusrini, D. 2013. Isolasi, Identifikasi dan Uji Aktivitas Senyawa Alkaloid Daun Binahong (Anredera cordifolia (Tenore) Steeniss). 1(1): 196-201.

7. Rahmah, R.2014. Isolasi dan Uji Efektivitas Antimalarial Isolat Senyawa Alkaloid Tanaman Anting-anting Secara In Vivo Pada Mencit Jantan [Skripsi]. Jurusan Kimia Fakultas Sains dan Teknologi UIN Maulana Malik Ibrahim, Malang.

8. Harbone J.B. 1987. Metode Fitokimia, Penuntun Cara Modern Menganalisis Tumbuhan. ITB, Bandung.
9. Gandjar I.G dan Rohman. 2007. Kimia Farmasi Analisis. Pustaka pelajar, Yogyakarta.

10. Nassel, F.M., 2008. Isolasi Alkaloid Utama dari Tumbuhan Lerchea interrupta Korth. BPOM, Jambi.

11. Rambet, G. L., Waworuntu, O., Gunawan, P. G. 2017. Uji Konsentrasi Hambat Minimum (KHM) Perasan Murni Bawang Putih ( Allium sativum) Terhadap Pertumbuhan Candida albicans. Jurnal Ilmiah Farmasi (PHARMACON). 6(1).

12. Geisler J, Thompson T. 2016. Choosing the best Detection Method: Absorbance vs. Flourescence. Journal of IMAB- Annual Proceeding. 12(2):9-16

13.Maftuhah, A., Bintari, S.H.,Mustikaningtyas, D.2015. Pengaruh Infusa Daun Beluntas (Pluchea indica) Terhadap Pertumbuhan Bakteri Staphylococcus epidermidis. Unnes Journal of Life Science.4(1): 60-65.

14. Setiabudy $R$ dan Gan H.S Vincent.1995. Antimikroba. Famakologi dan Terapi Ed 4. Jakarta : Gaya baru. Hal 571-3. 